\title{
IN SEARCH OF A PHARISEE
}

\author{
D.R. de Lacey \\ Summary
}

Although much criticised recently, the picture of First-Century Judaism as dominated by Pharisaic legalism still predominates even in major recent studies and standard works. J. Neusner has attempted an alternative model for understanding the Pharisees, which has in turn been criticised by E.P. Sanders. This study illustrates the problem, examines the debate and argues that the major issue in reconstructing pharisaism is lack of sensitivity to the nature of the sourcetexts. A refinement of Neusner's model is proposed as more in accord with the evidence we have.

\section{Introduction}

To most students of the period, First-Century Judaism is politically and religiously dominated by the Pharisees, ${ }^{1}$ who in turn are dominated by a desire to heap 'line upon line and precept upon precept', in no coherent fashion, in order to bring all of life under the control of the Torah. ${ }^{2}$ They are simultaneously smug and despairing, hidebound by tradition and innovative. What little we learn of their spiritual life is the formalism of mere ritualistic and external observance, ${ }^{3}$ crass

\footnotetext{
${ }^{1}$ The 'all powerful Pharisees' (J. Jeremias, Jerusalem in the Time of Jesus (Philadelphia, Fortress Press 1969) 265). Sadducean opposition was quite ineffectual: 'The Sadducees, generally speaking, were never [sic] able to put their views into practice even when they were in power' (S. Safrai and M. Stern, The Jewish People in the First Century CRINT 2 (Assen, van Gorcum 1974) 612); this makes the concept of 'being in power' somewhat puzzling). They openly despise and are despised by the 'am ha-'aretz, the common people (exclusively fools, knaves and sinners), who yet for inscrutable reasons spend their lives trying to emulate pharisaism (A. Oppenheimer, The 'Am Ha-Aretz (Leiden, Brill 1977) esp. ch I). Hence so many implausible modern suppositions, such as the one that precious glass if 'defiled even in a minor degree' was 'barred to a large section of the community' (CRINT 2.830).

${ }^{2}$ Or rather, their own interpretation of, and additions to, the Torah. Scholars sometimes appear to have (unacknowledged) difficulties with correlating these reactionary and innovative elements.

${ }^{3}$ Even when there are close parallels with Christian materials, as for instance in prayer to 'our Father' (see P. Grelot, 'Une mention inaperçue
} 
materialism, ${ }^{4}$ superstition, 5 and inconsistency. ${ }^{6}$ Such comments are made without any indication that the authors regard them as contentious. And this is not merely the uncritical scholarship of a bygone era. The revised Schürer was hailed as 'Simply the most important work on the history of the Jewish people ... published in the 20th Century' even by the man who must be the most prolific writer on early Jewish traditions; ${ }^{7}$ together with the Compendia it is probably now the major authoritative source on the subject for many students. Yet both of these repeat the travesties. The purpose of this paper is to raise a voice in protest both against the portrait of pharisaism they represent ${ }^{8}$ and more significantly the attitude to texts which underlies it; to assess the different approaches of Neusner and Sanders, and to offer a somewhat more nuanced model. I suggest that the pharisaic raison d'etre is a striving toward the highest holiness, as epitomised in the priestly service and expressed in the regulations of the Torah concerning purity. ${ }^{9}$ But since this is a religious ideal rather than an issue of torah-ordinance, it may co-exist with the realities of secular life.

de "Abba" dans le Testament Araméen de Lévi", Semitica 33 (1983) 101-8), it is somehow 'known' that the parallel is only formal and without substance: see e.g. A. Hamman, 'La Prière', ANRW II.23.2, 1190-247; or H.R. Balz, Methodische Probleme der neutestamentlichen Christologie (Neukirchen, Neukirchener-Verlag 1967) 113.

${ }^{4}$ E.g. G.G. Stroumsa, 'Form(s) of God': Some Notes on Metatron and Christ', HTR 76 (1983) 269-88.

${ }^{5}$ E.g. J. Maier, Geschichte der jüdischen Religion (Berlin, de Gruyter 1972) 37f.

6E.g. W.D. Dennison, Paul's Two-Age Construction and Apologetics (Lanham NY, University Press of America 1985) 20.

7J. Neusner, Ancient Judaism-Debates and Disputes (Chico, Scholars Press 1984) $189-193$ (192).

8I shall concentrate primarily on their religious views, and only on the first century, thus ignoring the many and thorny issues surrounding their political status and power at other times.

${ }^{9}$ This does not necessarily entail that they were a group identifying itself as the true Israel living in accordance with Ex 19.6, as Neusner's model is often understood. 


\section{The Revised Schürer}

The new History of the Jewish People in the Age of Jesus Christ ${ }^{10}$ is a work of enormous value. But a brief annotated catena may serve to demonstrate some of the problems faced by those who would follow its use of ancient texts and the consequent assessment of pharisaism. ${ }^{11}$

'Their party [the Pharisees'] was the nucleus of the nation, distinguishable from the rest only by their greater strictness and consistency. The basis of their endeavour was the Torah in all the complexity given it by centuries of work on the Torah scholars. Its punctilious realization was the beginning and end of their efforts' (389). This appears as a summary of the nature of pharisaism. Yet it seems to be simply a repetition of Josephus' affective language; ${ }^{12}$ at best it would be biased, at worst merely a statement of what Josephus would like the case to be; indeed, the case is probably worse still. In a careful study Mason has shown that Josephus' statements about Pharisaic

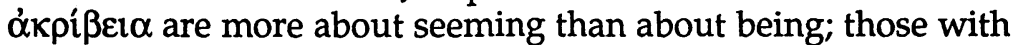
true $\alpha$ ki $i \beta \varepsilon 1 \alpha$ are the priests (supremely himself, Vita 9) and the Essenes. ${ }^{13}$ Thus even on Josephus' own terms SVM represents a major misunderstanding of the text; but it is enough to permit them the conclusion 'No peculiarity emerges from this characterization of pharisaism which might distinguish it from Judaism in general during the period of the Second Temple' (395). Given the method, this is hardly surprising.

'The outstanding prominence accredited to the Pharisees in the ancient sources may no doubt in part [sic] be attributed to the fact that rabbinic traditions exclusively represent and uphold a Pharisaic point of view, and also that Josephus was one of their number. Nevertheless, it can scarcely be a co-

${ }^{10}$ E. Schürer, revised by G. Vermes and F.G.B. Millar, (Edinburgh, T. \& T. Clark 1973-), henceforth SVM. References are to Vol. 2 unless otherwise indicated.

${ }^{11}$ Precisely the same could be done, with very little effort, in the case of CRINT 2.

12E.g. Josephus, BJ 1.110; cf. S.J.D. Cohen's judgment of such scholarship as 'paraphrases of Josephus with footnotes' ('The Political and Social History', in Early Judaism and its Modern Interpreters edd. Kraft \& Nickelsberg, (Atlanta, Scholars' Press 1986) 41.

13S. Mason, Flavius Josephus on the Pharisees (Leiden, Brill 1991) especially

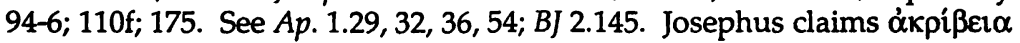
for all the Jews; Ant. 4.309, cf. Ap. 2.149, 175, 257. 
incidence that. . .most of the more memorable Torah scholars proceeded from its ranks' (389). This is simply an assertion that since only pharisaism survived it must have been normative. The logic is non-existent. The Torah scholars in question, of course, are 'memorable' merely to the Pharisees' own spiritual descendants. Doubtless had Yohanan ben Zakkai failed in his struggles against the priesthood after 70 , we would have had a very different group of 'memorable' Torah scholars to consider today.

A discussion of meek Pharisaic acceptance of all the oral Torah ends with the comment 'This is the principle alluded to by Josephus's statement that the Pharisees never contradict the teaching of those who are older in years' (391); cf. 'So remote were they [the Sadducees] from the Pharisee principle of absolute authority that they actually believed it commendable to contradict their teachers' (408). Quite apart from the psychological improbability of conducting debate without the possibility of contradiction, one need only note the form of the vast majority of even the earliest rabbinic materials-precisely a collection of debates over issues and dicta-to see the impossibility of taking Josephus' statement at face value. As $\mathrm{L}$. Feldman, the editor of the Loeb text, comments at Ant. XVIII 17, 'even a cursory examination of the Talmud will reveal that the Pharisees were no whit inferior to the Sadducees in the skill of disputation'-but then even he feels obliged to defend Josephus' integrity and so assumes that he means here what he elsewhere describes as the Sadducees' boorishness. Yet what of the tradition of hot, perhaps bloody, dispute between the Houses? ${ }^{14}$ This hardly supports the portrait of peaceable, loveable Pharisees contrasted to disputative Sadducees.

'Josephus [states that]. . .according to Pharisaic teaching, everything that happens comes about through God's providence; therefore it must be assumed that he also co-operates in human actions both good and bad. But this is a genuinely

${ }^{14}$ In jShab 3c; cf. MShab 1.4 and bShab 17a. M. Hengel, The Zealots (Edinburgh, T. \& T. Clark 1989) 199-207 argues that the tradition is early. Sanders, Jewish Law, 88 follows Neusner, Rabbinic Traditions in reinterpreting it merely as indicating early Shammaite dominance, but there seems to be a little special pleading in that. 
biblical view ${ }^{15}$. . This systematization [between Sadducees, Pharisees and Essenes] is certainly the weakest point in Josephus's argument. But even here there may be something true. It is possible [sic] that for the Essenes the divine factor, and for the Sadducees the human, occupied the foreground. The Pharisees in any case adhered to both lines of thought with equal determination. . .Here too, therefore, the Pharisees represented not a sectarian viewpoint but the main outlook of Judaism' (393f). This is a quite remarkable argument, presupposing as it does that Josephus' report is inaccurate, and yet finding ('in any case') data which are not even in that report to present as fact. Logic is lacking; it is not impossible that only a 'sectarian viewpoint' should preserve the 'genuinely biblical view' (were such a thing to be identifiable).

'The nature of the Sadducees does not stand out as sharply as that of the Pharisees. The scanty statements supplied by the sources cannot easily be unified. 16 The reason for this seems to be that the Sadducees themselves were not a consistent phenomenon like the Pharisees, but a complex one, requiring to be considered from various angles' (404). It is difficult to comment on the logic behind this argument, for it has no existence.

In legal matters 'they [the Sadducees] were more severe than the Pharisees';17 yet immediately their far more lenient attitude to false witnesses in capital cases is noted, to be excused with the comment 'These differences were obviously [sic] not really differences of principle' (409). The same logic explains away the major calendrical difference in MMen 10:3: "This difference, however, is so purely technical that it merely gives expression to the exegetical outlook of the Sadducees with its non-acceptance of [Pharisaic!] tradition. It is not an issue of principle' (410f). It is unfortunate that no indication is given of the criteria needed for identifying what a Sadducee or Pharisee of the first century would regard as a matter of 'principle'.

${ }^{15}$ It is difficult to see what rôle this piece of affective language plays in a scholarly argument.

16In contrast, no doubt, to statements which survive about Pharisees or the early Christians.

${ }^{17}$ This is 'according to Josephus', 409, but the following indicates that SVM accept the verdict. 
Commenting on the 'religious revival' in the Maccabean period, SVM upbraid the obduracy of the 'ruling priestly aristocracy' (whose job, we should recall, was precisely to maintain the religious life of Israel at its focal point and the leading laity who 'refused to be bound by the achievements of the previous few centuries 18 in regard to both the interpretation of the Torah and the development of religious views', 413). Further comment is surely superfluous.

A veneer of critical respectability is occasionally applied to this travesty by the use of such phrases as 'according to the tradition' or 'the story is told. . $\therefore$ ', but the impression remains that the tradition or the story is at least relevant to the reconstruction. Thus we are solemnly told, without comment, that The gate of the Temple itself is said to have creaked so loudly when it was opened that the sound could be heard as far away as Jericho'; 'There were in addition [not even 'it is said' here]. . a herald whose voice was so powerful that it could be heard as far away as Jericho'.19 Was anyone ever intended to take this tradition literally? The source runs thus:

He that slaughtered never slaughtered until he heard the noise of the opening of the great gate. From Jericho they could hear the noise of the opening of the great gate; from Jericho they could hear the sound of the 'Shovel'; from Jericho they could hear the noise of the wooden device which Ben Katin made for the laver; from Jericho they could hear the voice of Gabini the herald; from Jericho they could hear the sound of the flute; from Jericho they could hear the noise of the cymbal; from Jericho they could hear the sound of the singing; from Jericho they could hear the sound of the Shofar; and some say, even the voice of the High Priest when he pronounced the Name on the Day of Atonement; from Jericho they could smell the smell at the compounding of the incense. R. Eleazar b. Diglai said: My father's house kept goats in the mountain of Machwar [across the Dead Sea in Perea], and they used to sneeze from the smell at the compounding of the incense. ${ }^{20}$

${ }^{18}$ Aliter, these modern influences from without.

${ }^{19} \mathrm{SVM} 2,286 \mathrm{f}$ and 288 . In each case the reader is referred only to MTam 3.8. Jericho is more than $20 \mathrm{~km}$ over the hills from Jerusalem.

20MTam 3.7f in Danby's translation (as all quotations from the Mishnah in this paper); the text in the Soncino Talmud is significantly different. A parallel tradition is found in bYom 39b, and a partial parallel but partial contradiction in bYom $20 \mathrm{~b}$. 
One is tempted to suppose that despite Sandmel's strictures of long ago 21 the major source for such an approach is still StrackBillerbeck. Its essential weakness is that it tends to treat the sources as our forebears treated the Gospels: promiscuous and non-tendentious (in that sense, theologically vacuous) collections of all the traditions currently circulating in the community; an immediate window to reality. A thorough reexamination of the sources, and appropriate methods of using them, is urgently called for. We cannot today begin a discussion of Jesus without first asking of each evangelist, Why did he write? What are his concerns, his message? What are the origins and previous history of the materials he uses? I see no similar concern in works like SVM to interrogate the 'background' materials, and to ask of the Talmud, for instance, what the final redactor was trying to say to his own time. ${ }^{22}$ Without some understanding of that, we are in no position to say how this material could yield useful information about our period. Citing rabbinic dicta in vacuo can prove anything, and therefore prove nothing. ${ }^{23}$

\section{A Model of Purity: Neusner's Pharisees}

It has been the life work of J. Neusner to ask precisely these questions of the rabbinic materials, and in major series after major series of texts he has explored these issues; producing new translations; ${ }^{24}$ distilling out the pre-70CE traditions; ${ }^{25}$ seeking the intentions of those who wrote the Mishnah and the

21S. Sandmel, 'Parallelomania', JBL 81 (1962) 1-13.

22 Or to what extent the farrago of improbabilities cited above is simply an elaboration (to what purpose?) of the tradition that the squeak of the opening gate was the signal to begin the morning sacrifice. SVM, like other studies on Josephus and the rabbinic materials, have extensive discussions on use of sources, but these appear to influence the subsequent reconstruction of history in no way whatsoever.

23In particular at the very least we need to know whether a view was representative: anthologies such as Strack-Billerbeck remove that possibility. Other valuable clues (e.g. tone of voice!) are sadly past recall.

${ }^{24}$ The Talmud of Babylonia: an American translation (Chico, Scholars Press 1984-).

${ }^{25}$ The Rabbinic Traditions about the Pharisees before 70, 3 vols. (Leiden, Brill 1971). 
Talmuds; 26 and teasing out the self-understanding of the Pharisees. His conclusions are well-known: The traditions about the Pharisees before AD 70 which are specifically attributed to individuals or the Houses consist of 371 units, and 'no fewer than 229, approximately 67 per cent of the whole, directly or indirectly concern table-fellowship' ${ }^{27}$ Hence,

The Pharisees were Jews who believed one must keep the purity laws outside of the Temple. Other Jews, following the plain sense of Leviticus, supposed that purity laws were to be kept only in the Temple, where the priests had to enter a state of ritual purity in order to carry out such requirements as animal sacrifice. They likewise had to eat their Temple food in a state of ritual purity, while lay people did not. To be sure, everyone who went to the Temple had to be ritually pure. But outside of the Temple the laws of ritual purity were not observed, for it was not required that noncultic activities be conducted in a state of Levitical cleanness.

But the Pharisees held that even outside of the Temple, in one's own home, the laws of ritual purity were to be followed in the only circumstance in which they might apply, namely, at the table. Therefore, one must eat secular food (ordinary, everyday meals) in a state of ritual purity as if one were a Temple priest. 28

Pharisees, then, in our period, were a lay group who wished to bring the purity of the Temple into the common home. As the Essenes appear to have applied to themselves the model of the army of God, applying to themselves the legislation of the war-camp, so the Pharisees saw themselves as the heart of the 'kingdom of priests' (Ex. 19:6) which was Israel. The attractiveness of the model lies as much in its simplicity and cogency as in the impressive statistics with which Neusner presented it. For the first time it made sense for someone to opt to be a Pharisee.

Many modern scholars have accepted and worked with Neusner's model.29 A recent and sustained attack has come,

${ }^{26}$ See e.g. A history of the Mishnaic law of Purities (Leiden, Brill 1974-77); .. .of Holy Things (1978-80);. . of Women (1980); . . of Appointed Times (19813); . . of Damages (1983).

27J. Neusner, From Politics to Piety (NY, KTAV 1979) 86; cf. Rabbinic Traditions 3.303f; 297.

28Neusner, From Politics to Piety, 83.

${ }^{29}$ See e.g. A. Saldarini, Pharisees Scribes and Sadducees in Palestinian Society (Edinburgh, T. \& T. Clark 1989) 206 and all of ch. 10. 
however, from E.P. Sanders. 30 He presents three main arguments:

(1) Neusner has misunderstood the texts he cites. They are not in the main about table-fellowship or priestly purity; they do not support his model of a priestly self-understanding.

(2) The texts themselves indicate that the model of priestly purity was still being debated at a much later stage; it cannot then have been presupposed by the pharisees.

(3) It would be sociologically impossible for lay folk to live as priests; they would have had neither the time nor the resources necessary to carry out such a programme.

Sanders writes with wit and erudition, if also with some heat when he makes his point. But for all his learning, there are significant areas where I believe Sanders is, in part at least, mistaken. I suggest that he has mis-read Neusner, he has mis-read some of the texts, and perhaps most of all he has misread the very conception of self-identity. These three correspond in a rough and ready sort of way to the three prongs of his attack as identified above.

\section{Sanders on Neusner}

Sanders complains that Neusner is inconsistent. ${ }^{31}$ His purpose in highlighting this is precisely to deny the possibility of claiming that there is a definitive Neusner position, that 'Neusner has shown that. . '; yet his attack is consistently on what he presents as Neusner's position; namely that Pharisees

\footnotetext{
${ }^{30}$ Most extensively in E.P. Sanders, Jewish Law from Jesus to the Mishnah (London, SCM 1990) and again in Judaism. Practice \& Belief 63 BCE-66 CE (London, SCM 1992).

${ }^{31} \mathrm{E} . \mathrm{g}$. in his attitude to the concept of Oral Law, which in some writings, dropping his critical stance, he regards as really being 'teachings handed on by tradition from Sinai' (Neusner, Mishnah before 70 (Atlanta, Scholars' Press 1987) 132-9, quoted in Sanders, Jewish Law, 110-12). But it is to be noted that in the very passage cited by Sanders, Neusner adds the significant rider, 'Viewed from the perspective of Judaic faith'. I would not argue that Neusner (uniquely among scholars?) never contradicts himself; but here at least the perspective from which the statement is made has been clearly enunciated: it is the perspective of faith, not that of scholarship. It is really rather irrelevant whether this perspective or the critical one is Neusner's real position, as long as the reader looks for the arguments rather than the conclusions.
} 
saw themselves as trying to live in priestly purity. In fact Neusner generally 32 claims rather less than Sanders' response suggests. He often speaks of temple purity (as in passages Sanders cites); and even in his stronger statements he only affirms that they lived 'as if' priests, not 'as' priests. The difference, we shall see, is not inconsiderable. Thus Sanders counters a comment that the tables at home had to be as pure as the Lord's table with the argument that 'In pharisaic/rabbinic material there is no replacement purity rite [viz for the sacrifice of a goat and a bull on the Day of Atonement] for the table'.33 He therefore implies that he sees the essence of Neusner's model as being a pharisaic claim to replace the temple priesthood. As we shall see, the 'replacement' is important in Sanders' critique, and represents, I believe, a fundamental misunderstanding. That the priestly sacrifice might itself achieve this purification is not even considered. This means that sometimes Sanders' criticisms just miss the mark. Consider the following:

Neusner supposed that biblical purity laws applied only to the priests and the temple, so that accepting any purity law showed the desire to live like a priest. It is remarkable that. . he wrote this:

The Pharisees. . .believed that one must keep the purity laws outside of the temple. Other Jews. . .supposed that purity laws were to be kept only in the temple. 34

This is not, as Sanders appears to think, a claim that Pharisees usurped the priests' place. Similarly, when he states that 'Neusner himself sees (but not its significance) that the wine from which the priests' portion is removed is rendered impure', 35 the underlying assumption (Pharisees drank impure wine, therefore Pharisees did not live in priestly purity) is invalid. It is perfectly reasonable to suppose that they strove for a purity analogous to, but neither identical to nor a

32I confess that I have not read the entire Neusner corpus, and I have certainly not re-read it with pen in hand in order to substantiate this claim. Fortunately Sanders does not think highly anyway of counting instances. For a clarification and re-statement of his position over against Sanders, see his 'Mr. Sanders' Pharisees and Mine', SJT 44 (1991) 73-95. Much of this article was written before I had seen it, and I am grateful to Dr S. Mason for drawing it to my attention and posting me a summary.

${ }^{33}$ Sanders, Jewish Law, 177.

34Sanders, Jewish Law, 176, quoting Idea of Purity, 65.

35Sanders, Jewish Law, 174. 
replacement for, that of the priests. Since the Torah explicitly forbad the laity from eating Holy Things, that or something like it must surely be entailed in Neusner's model. ${ }^{36}$ Neusner may well at times overstate his case, and it is clear that many of Sanders' objections to individual cases presented by Neusner are correct. ${ }^{37}$ Sanders' charges of muddle and inconsistency may have force; however, the model of pharisaism which Neusner has presented must be assessed quite apart from any criticisms of his own clarity or consistency.

\section{The Texts}

The texts we have to work with are a strange and difficult collection. As well as assumptions which may be reasonably manifest there are others which may go unnoticed by the interpreter. One small illustration of the difficulty of assessing an author's handling of the texts: in Jewish Law, 7 Sanders cites Nehemiah 13:15-22, but sees no need to comment on whether the guard-duty could itself be counted as work; despite the fact that a discussion of 1 Maccabees 2:29-41 immediately follows. Assessing an ancient text is not a straightforward task. Neusner has himself challenged some of Sanders' exegesis, 38 and I do not intend to fight his battles for him even were I competent to do so. It is rather the broader question of handling the sources on which I wish to comment.

Sanders relies to a large extent upon Josephus for his portrait of the Pharisees. This is not perhaps unreasonable,

${ }^{36} \mathrm{Cf}$. the argument of A.J. Peck, The Priestly Gift in the Mishnah (Chico, Scholars Press 1981), that there was considerable fascination with, and discussion about, the fact that by setting aside the tithe the laity actually created a holy thing; that necessarily in contrast with the nine-tenths which remained.

37In particular it is clear that Neusner's head count is unrealistic, and that many of the laws adduced by him which are about purity are not about the model of 'priestly' purity, but in the Torah itself are binding upon all Israel. There is nothing 'sectarian' about keeping them.

${ }^{38}$ See for instance J. Neusner, Understanding Seeking Faith. Essays in the Case of Judaism. Volume One: Debates on Method, Reports of Results (Atlanta, Scholars Press 1986); 'From Moore to Urbach and Sanders: Fifty Years of 'Judaism'. The End of the Line for a Depleted Category'; RelStTh 6 (1986) 7-26. These of course do not address the issues under discussion here. The more recent, but equally robust, response in SJT (see n. 31 above) does not focus on details of exegesis. 
since he believes that Josephus was one himself, 39 but other such believers are somewhat more sceptical about the value of Josephus' evidence. 40 Yet even so his use of Josephus is at times odd. 'The Pharisees accepted both [providence and freewill]: election by grace, obedience by free will. They were not alone in combining the two, as we saw when we discussed the Essenes. . .we must suppose that this union of apparent opposites is more common-Jewish than distinctively Pharisaic' (Judaism, 419). The sources for this, however, are statements in which Josephus is quite explicitly contrasting the Pharisees' attitude to fate with that of the Essenes.41 If Josephus was so wrong in that, how can the 'common-Jewish' position be confidently extracted from his text?

Josephus says the Pharisees were lenient in comparison with the Sadducees, and behold MSanh is lenient; Sanders gives a few examples (Judaism, 420). It is not clear though how the fiercest of Sadducees could improve on MSanh 11.3f (death by strangulation for those whose phylacteries do not conform to the words of the Scribes) or MMakk 3.13 (And he that smites [the 40 stripes], smites. . .with all his might).42 And it was a Pharisee who hounded the early church almost to extinction

${ }^{39}$ I can find no reference to Mason's arguments against this interpretation of Josephus, even though in other places he cites Mason's work.

${ }^{40} \mathrm{He}$ can invent, exaggerate, over-emphasize, distort, suppress, simplify, or, occasionally, tell the truth. Often we cannot determine where one practice ends and another begins. Thus it is easy to destroy Josephus' account, but nearly impossible to construct a more truthful one. . .his Pharisaism is of the most dubious variety, and he did not discover it until the nineties of our era. In the sixties he was a Jerusalem priest', S.J.D. Cohen, Josephus in Galilee and Rome, 181, 223f. But Sanders does not even discuss 'The alternative. . .that Josephus oversimplified their position' (Jewish Law, 107).

41It is also not true to say that Josephus' Pharisees combined providence and freewill in the way suggested here. Elsewhere Sanders says that they 'did not work them out philosophically, just as they did not worry about combining monotheism and dualism. They did not see the need to solve the problem' (Judaism, 251). We have not a shred of evidence for this; it is just that Josephus does not bother to tell us how they might have done so. Perhaps Sanders thinks they were just too busy puzzling out the philosophical problems posed by the sacrificial system ('Since offerings and sacrifice were such large parts of ancient religion, thoughtful people reflected on their value and meaning', ibid.).

${ }^{42}$ Compare also SVM 2.409, discussed in n. 16. 
(Gal. 1:13). As observed above, such proof-texting can establish nothing.

Sanders rebuts the suggestion that Pharisees practised religious apartheid with the argument that 'there is not a word about social isolation in any of the ancient literature. Josephus' silence on this point is especially striking. He liked recounting curious aspects of religious behaviour, and he wrote about the Essenes'. . .separatism, at some length. . .Analogous practices on the part of the Pharisees would have deserved some comment from Josephus, but there is none' (Judaism, 429). It is a brave exegete who can claim to understand an ancient author's motive, but a study of Josephus' text will indicate that his 'liking' is not nearly so great as Sanders suggests. The Essenes are the only group who are described by Josephus at any length, and it is implausible to suppose that there were no 'curious aspects of religious behaviour' among Pharisees or Sadducees to have deserved his comment. A similar approach is seen in his reading of MNidd 10.6f, on which he comments 'Here they had a perfect chance to say that all their food was holy and that no impure woman could touch it. They passed up on the chance' (Judaism, 432f). Such assumptions that a document must say what we would like it to say has bedevilled other areas of study 43 but should have no place in critical scholarship. This seems to be precisely the 'flat' reading of an ancient text which Sanders himself elsewhere deplores (Jewish Law, 287).

A rather different mis-reading occurs, I think, when in denying the existence of a double Torah Sanders points out that 'In Parah 11.4-5 purity laws are distinguished. People who are impure according to the 'words of torah' are guilty if they enter the temple, while those who are impure according to the 'words of the scribes' are not. Failure to observe the words of the scribes is not transgression' (Jewish Law, 116). Apart from the existence of passages like MSanh 11.3f, where the words of the scribes are actually more binding than the Torah,44 it is clear

${ }^{43}$ E.g. the extent to which Paul knew traditions about Jesus; see M.B. Thompson, Clothed With Christ (Sheffield, JSOT 1991).

${ }^{44}$ See n. 41. I would not try to defend for a moment the historicity of these supposed laws. The point is simply that such selective proof-texting can be used to support almost any position, and is therefore worthless. Sanders deals with MSanh 11.3f in Jewish Law, 117, but fails to comment on the extremity of the punishment for disobedience. 
that Parah is arguing for two levels of impurity, not two different levels of law. Again it seems that Sanders thinks too readily of identity or replacement, where the rabbis, and perchance their pharisee forerunners, thought more in terms of analogy. Note also Sanders' handling of MToh 8.2, which states that vessels left with an 'am ha-'aretz will not become impure with corpse-impurity if they are known to belong to a priest (Jewish Law, 238). There is no suggestion in the text (as Sanders infers) that the 'am ha-'aretz will in such cases (and only in such cases) carefully remove all corpses before taking charge of the pots; or refrain from mourning his dead should the eventuality arise. It is doubtful indeed that anyone would be expected to do so.45 To use Sanders' own approach, would we not if he were right expect lengthy debates on the status of a nonpriestly pot left with the same 'am ha-'aretz at the same time? Similar problems are seen with respect to MHag 2.7, to which we shall return.

This brief discussion is intended to suggest that Sanders' approach to the texts is not adequately nuanced. For all his complaints about the 'flat' readings by others (Jewish Law, 287) he is perhaps not himself guiltless.

\section{Sociological Factors}

Sanders is certainly correct to raise the question of 'what it would mean, in practical terms, to apply to ordinary food the purity laws which governed the priests and the temple' (Jewish Law, 149). As the ensuing discussion makes clear, a little sociological imagination can be invaluable in the art of debunking. ${ }^{46}$ But his conclusion is incorrect. He claims that the inexorable logic of supposing that food was to be eaten in purity leads not only to long periods of fasting (whenever one is not in a state of purity) but also to an impossibly busy life, when for instance a Pharisee paterfamilias has to take on all the chores of his menstruant wife. But this is based on precisely the 'flat' reading of the texts which he upbraids. As he himself acknowledges, even the priests themselves could not have kept

${ }^{45}$ Even a priest was allowed to mourn his next-of-kin (and incur the concomitant impurity), the 'am ha-'aretz could not know in advance that he might not be called upon to do likewise.

46Sanders, Jewish Law, 155-62, cf 183; 233 and the text at note 18, above. 
the purity rules to that extent. 47 Other 'as if' models 48 have little difficulty in accommodating the realities of life; why should the Pharisees be different? Such arguments cannot therefore destroy the model. This assumption which pervades Sanders' argument (they did not do everything that priests ought to do, therefore they did not see themselves as living in priestly purity) misinterprets the religious imagination.

\section{Sanders' Pharisees}

If Pharisees are not then a community of pious laymen who bind themselves to live as priests, what are they? In Judaism, 418-51, Sanders offers an assessment, under 10 main heads, of 'distinctive or partially distinctive Pharisaic views' based on what he sees as distinctive in the traditions. The result is frankly disappointing, in that very little seems to be distinctive at all. Some of the issues (leniency, $\alpha \kappa p i \beta \varepsilon \imath \alpha$ ) we have already discussed. In others (providence and freewill, devotion to God; tithes, exclusivism) Sanders himself finds little 'distinctive'. We seem to be left with something like the Pharisees of ninteenthcentury imagination: a group with some arbitrary extra-biblical traditions they insist on imposing. ${ }^{49}$ Sanders is aware that he leaves himself open to this charge, and tackles it in Jewish Law, 252-4. But despite his (perfectly reasonable) defence of the

47 Sanders, Judaism, 440; cf. Jewish Law, 233.

48Paul's model of living 'as if' in the eschaton, for instance; or the popular evangelical perspective of living 'as if' the Lord were to return within the very near future.

49'Their traditions were their own; they [the traditions] made them Pharisees' (Sanders, Jewish Law, 128); 'One of the main distinguishing marks of the Pharisaic party was commitment to "the traditions of the elders" as supplementing or amending biblical law' (Sanders, Judaism, 421); The Pharisees were what they appear in Josephus to be: a group of mostly lay people who were concerned to study, interpret and apply the biblical law, and who did not fear to go beyond it. . Their close attention to law and tradition made them stand out, not because only they cared for the law, but because they were so exact and because they applied law and tradition to even more areas of life than did most Jews' (Sanders, Judaism, 444). It should be clear from the above that even in Josephus the only distinguishing feature in this is their specific traditions (whatever they may be). It is ironic that the major distinguishing feature tackled by Sanders is 'eruvin, which he describes as 'a relaxation of the law', distinguishing Pharisees sharply from both Sadducees and Essenes precisely by being less 'strict' (Judaism, 425). 
Pharisees against legalism he gives no help to the reader to find their 'interior attitude and. . .soteriology' (Jewish Law, 252); and rather seems to undermine his case when he writes 'The point of being a party is to have special rules. . . Had other people adopted their distinctive practices, which they could have done without too much difficulty, they would have been Pharisees too' (Judaism, 450). This may not mean that Pharisees were a group who were distinguished merely by doing certain distinctive things, but I cannot see how. On a gross sociological level, boundary-markers do indeed consist in certain practices, but these are only expressions of inwardly-held beliefs. 50 It is difficult to imagine a Jewish group arbitrarily changing its calendar, for instance, simply in order to distinguish itself from the cultus. 51 It is no explanation of the inner coherence of pharisaism to suggest that they were (inscrutably) freer than others to indulge in creative developments. 52

\section{Purity Reconsidered}

Let us then look again at the purity model. Sanders is well aware that purity was indeed a significant issue for the Pharisees. They developed their own rules about it (even their own impurities), and made what Sanders calls 'minor symbolic gestures' towards priestly purity, 53 but he thinks their model

${ }^{50}$ The expression may of course bear no intrinsic relationship to the marker; there is nothing inherently red about socialism. But in precisely such cases, wearing a red scarf does not make one, or even show one to be, a socialist.

${ }^{51}$ As Sanders suggests of the Essenes, Jewish Law, 85. It is even harder to understand how they could then criticise the Jerusalem authorities for not joining them.

52 Unlike the Sadducees, the Pharisees did not have to base everything on the law, and so they could interpret it in a relatively straightforward manner and avoid the most fanciful midrash and excessively forced exegesis. Unlike the Essenes, they did not appeal to secret parts of the divine revelation' (Sanders, Jewish Law, 127, emphasis mine).

${ }^{53}$ Jewish Law, 192 cf. 233; Judaism, 438f. This is admittedly in contrast to the major social upheavals he imagines the priestly model to entail; yet it seems to be minor also in his assessment of their self-understanding; see the next note. 
was purely secular, 54 deriving from the common belief that even handling the priests' food must be done in purity. .5

He also cites MHag 2.7 as indicating respect for priests. All of this shows 'complete support of the priesthood. These signs of respect contrast greatly with harsh criticisms of other pietists'. ${ }^{56}$ In fact MHag 2 perhaps points the way towards a rather different assessment of Pharisaic self-understanding:

5. For [the eating of food that is] unconsecrated or [Second] Tithe or Heave-offering, the hands need to be rinsed; and for Hallowed Things they need to be immersed; and in what concerns the Sinoffering water, if a man's hands are unclean his whole body is deemed unclean.

6. If a man immersed himself to render himself fit to eat of unconsecrated produce, and his intention was confined to unconsecrated produce, he may not touch Second [Tithe]. If he immersed himself to render himself fit to eat of Second [Tithe], and his intention was confined to Second [Tithe], he may not touch Heave-offering. . .If he immersed himself for the sake of what has a higher degree of sanctity, he is permitted to touch what is of lower degree. If he immersed himself but without special intention, it is as though he had not immersed himself at all.

7. For Pharisees the clothes of an Am-haaretz count as suffering midras-uncleanness; for them that eat Heave-offering the clothes of Pharisees count as suffering midras-uncleanness; for them that eat of Hallowed Things the clothes of them that eat Heave Offering count as suffering midras-uncleanness; for them that occupy themselves with the Sin-offering water the clothes of them that eat Hallowed Things count as suffering midras-uncleanness. Joseph $\mathrm{b}$. Joezer was the most pious in the priesthood, yet for them that ate of Hallowed Things his apron counted as suffering midras-uncleanness. Johanan b. Gudgada always ate [his common food] in accordance with [the rules governing] the cleanness of Hallowed Things, yet for them that

54 T think it most likely that the Pharisees had a desire for purity for its own sake. Purity symbolized not just the priesthood, but Godliness' (Jewish Law, 192).

55 . . . by the time of Judith it was regarded as being against the law for an impure person to handle the priests' food. . This was accepted, according to rabbinic literature, by the ordinary people' (Jewish Law, 106). It is not clear that his texts (Isa. 66:20, Judith 11:13; MTebul Yom 4.5) establish this view.

56Judaism, 434f. But an attitude to the abstract 'priesthood' might be very different from one towards those individuals who fulfil the rôle in practice. I find the interpretation in Peck, op. cit., far more persuasive. 
occupied themselves with the Sin-offering water his apron counted as suffering midras-uncleanness.

According to Sanders, this indicates that Pharisees were 'less careful than priests' families' about midras uncleanness (Jewish Law, 206); an ordinary person's garments were 'more likely' to have midras impurity than a Pharisee's (Judaism, 440; Jewish Law, 258). But it is clear that that is not its intent. This passage first of all outlines a vital principle for the religious imagination; that of intention. This is a factor which long antedates the formal doctrine of kawwanah, lying behind the earliest ritual burials. In that context our passage indicates a hierarchy of purities which has nothing to do with care or even the actual state of purity of individuals. ${ }^{57}$ Within this hierarchy Pharisees place themselves under priests, but only just ${ }^{58}$ and even the 'am ha-'aretz may have had their own sort of purity. ${ }^{59}$ In other words, there is no hint here of usurping or replacing priests, but there is a clear model of establishing a scale of purities, and moving as far towards the priests on that scale as possible.60 Long after 70, when it was realised that the Temple would not be rebuilt, we may surmise that this extension did indeed become a replacement, when one's own table might be seen more truly as an altar (bBer 55a). In that case we may well understand why later rabbis had to debate afresh all those issues which Sanders sees as denying the presupposition of a priestly model (Jewish Law, 171-3).

The same logic seems to lie behind legislation like MToh 8.5 'If the wife of an Am-haaretz entered the house of an

${ }^{57}$ 'Those who eat Heave-offering' is probably a general designation of the priests, whose state of purity cannot be perpetually guaranteed. But 'those who eat of Hallowed Things' (priests on active service) should already be in a state of full purity: midras-impurity would disqualify them. 58It is worth noting that in practice the rabbis were to accuse the Sadducean priests of serving in impurity; MNidd 4.1f.

${ }^{59}$ It is remarkable that the Tosefta debates whether a Pharisee zab may eat with an 'am ha-'aretz zab, but not whether he may eat with a pure 'am ha'aretz

${ }^{60}$ I would agree entirely with Sanders' judgment quoted in n. 53. But it is in danger of ignoring the fact that godliness was in practical terms focused on the Temple, and the priesthood therefore stood as an obvious model for godliness, especially as it was subjected in the Torah to more stringent rules of purity. Hence emulation is a better term than Sanders' (implicit) substitution. 
Associate to fetch out his son or his daughter or his cattle, the house remains clean, since she had entered without permission'. Here again the idea of intention, and accommodation to the realities of life, are clear. Neusner's model can survive without the need to exchange the nineteenth-century travesty of Pharisees hag-ridden with fear lest they transgress the least commandment by a twentieth-century one of Pharisees hagridden with fear lest they pick up the least impurity.

Such a model can also help us understand why the concept of the tevul yom 61 arose at all. Such a person's purity, although only partial, is sufficient to ensure that he or she cannot convey uncleanness to others; in other words, satisfies a desire for purity as well as the social demands of daily life in the real world.

Comparable to this extension of degrees of purity of the individual is the extension of geographical purity to the concentric circles focusing on the Holy of Holies (MKel 1.6-9; cf. MMiq 8.1). It is noteworthy that there is no discussion of how the presence of an 'am ha-'aretz home or a Roman pigsty would affect the holiness of the land. Those operate on a different conceptual level. Thus what Sanders notes as 'minor symbolic gestures',62 coupled with the remarkable extensions of impurity, may perhaps be only the expression of major symbolic structures with which the Pharisees understood themselves as they strove for purity and holiness.

There are other factors which would need to be examined in any comprehensive reconstruction of pharisaism. I have not discused at all what seems to be the major element in Josephus' portrayal: that they were a philosophical school analogous to the Stoics, who debated with the Sadducees on the relationship between predestination and freewill. It is not obvious what correlation could be drawn between that and the purity model. Then the Gospels seem to suggest that they were immediately recognisable 63 and this might be worthy of further

${ }^{61}$ One who immersed that day; i.e. is waiting for the evening to be clean according to the Torah. See MKel 1.5, 8; MTevul Yom 2.1, 4.

${ }^{62}$ See n. 52. One might imagine, to take a contemporary example, a bemused Pharisee describing a Christian eucharist as observed in most churches as a mere 'minor symbolic gesture' towards a common meal, and be exceedingly sceptical of any attempt to use it as a major element of a Christian self-identity.

${ }^{63}$ Not exclusively from the size of their tefillin, surely? 
exploration. Nor have I attempted to discuss the nature of 'purity'. One problem with studying the concept of purity is that it is only part of a cluster of ideas which also includes cleanness and holiness, and that these can be used in a variety of ways (ethical, cultic, neither, both). To proceed to investigate how the traditions understood the relationship between these various parts is an important next step, but one which must be left to another. 